A Large Indian Sea-Perch.

THE dimensions and weight of a sea-perch caught in December last by some native fishermen near Diamond Harbour in the River Hooghly seem to me to be worth recording.

Its length is nearly seven and a half feet, its girth just behind the shoulder is a little more than five feet nine inches, and its weight, the day after its capture, was four hundred and sixty pounds.

The fish is so old and worn that its specific identity must remain in doubt, but it agrees fairly well with Day's description, in the "Fauna of British India," of Epinephelus lanceolatus, Bloch.

The largest Indian zea-perch of which I can find any record is the one mentioned by Russell (quoted by Day under Epinephelus pantherinus and malabaricus), which was taken at Vizagapatam in January, 1786 , and measured seven feet in length, five feet in girth, and weighed upwards of three hundred pounds.

The scales of the Diamond Harbour monster are so altered by deposit that their accretion lines are very difficult to follow; but in a large scale from the shoulder I can count between 500 and 600 such lines, which are sometimes grouped in series of about eight, but oftener show no grouping at all.

Indian Museum, Calcutta, February 2.

A. Alcock.

\section{Attractions of T'eneriffe.}

THOSE members of the British Association who visit South Africa this year will probably desire to spend as much time as they can near their journey's end. But it is just worth mentioning that some of the oceanic islands en route have very special attractions. For instance, I write from Teneriffe, which has igneous rocks, cinder cones, and lava streams for the geologist; and for the botanist all zones of vegetation from the subtropics to the snows. The scientific literature of the island is at present more in German than in English. A single day's excursion, 2oooft. up into the hills by electric tram, is possible whilst the steamer waits to coal. A week would allow of a short tour to Orotava and across the mountains to Guimar, through some of the most interesting parts of the island.

HUGH RichardSON.

SAMUEL, PEPYS AND THE ROYAL SOCIETY. M AGDALENE COLLEGE, Cambridge, with 1 which the name of Samuel Pepys is indissolubly associated, held in his memory at the college on Thursday last, his birthday, a reunion which may become an annual event. Some of the institutions with which he was more especially connected were invited to send delegates to this gathering. Thus the Royal Society was represented by one of its secretaries and its foreign secretary. From the immortal Diary it appears that the first proposal that Pepys should join that Society was made to him in the spring of the year 1662 by his friend Dr. Timothy Clerke, who offered to bring him "into the College of Virtuosos and my Lord Brouncker's [P.R.S.] acquaintance, and to show me some anatomy; which makes me very glad, and I shall endeavour it when I come to London." Two vears, however, elapsed before his election. From the minute-books of the Society it appears that he vas unanimously elected and admitted on the same day (February 15, 1664)-a rapidity of procedure which contrasts with the much more leisurely action of the present day. He records that he "was this day admitted by signing a book and being taken by the hand by the President, my Lord Brunkard, and some words of admittance said to me. But it is a most acceptable thing to hear their discourse and see their experiments. ... After this being done they to the Crowne Taverne, behind the 'Change, and there my Lord and most of the company to a club-supper."'

NO. I 844 , vOL 7 I]
The meetings of the Royal Society in those days must have been a good deal more lively than they are at present. Robert Hooke, the most fertile and inventive genius of his time, was then "Curator of Experiments," and brought forward at each meeting either some ingenious contrivance of his own or some device provided by one of the members. This constant and exciting variety of practical demonstration would be entirely after Pepys' heart, gratifying his spirit of curiosity and his keen desire to increase his knowledge in every direction. Another feature of the meetings could not but gratify one of his most characteristic proclivities-his sociability and love of congenial company. The evening adjournments to the "club-supper"; at the Crowne Taverne behind the 'Change or to the Devil Taverne in Fleet Street would end off his day as he alvays delighted that it should end. These meetings for supper contained the germ of the Royal Society Club, the oldest extant records of which do not go back further than i743. This club consists of a limited selection of fellows of the Society who still dine together at some restaurant on the evenings of the Society's meetings.

At the time of Pepys' election the Society met at Gresham College, but a few years afterwards moved to Arundel House. An effort was then being made to raise money for the purpose of building a house in which the "virtuosos " might hold their meetings and place their library and apparatus. Among the other fellows, Pepys was applied to for a subscription. Under date April 2, I668, he writes, "with Lord Brouncker to the Royall Society, where they were just done; but there I was forced to subscribe to the building of a College and did give 4ol." certainly a generous donation at that time. $\mathrm{He}$ evidently had some reluctance to join in the scheme, for he thought that this canvassing for money " may spoil the Society for it breeds faction and ill will, and becomes burdensome to some that cannot or would not do it."'

The Royal Society held its annual meeting for the election of the council and officers on St. Andrew's Day, November $30-a$ date which is still kept sacred for the same purpose. But some of the usages that were formerly in vogue have disappeared. Thus Pepys writes on November 30, 1668, "To Arundel House and there I did see them choosing their Council, it being St. Andrew's Day; and I had his cross in my hat, as the rest had, and cost me $2 s$." The diarist himself had already been nearly selected to serve on the council, so well did he stand in the esteem of his fellow members. Only three years and a half after his admission into the Society he records that "I was near being" chosen of the Council, but am glad I was not, for I could not have attended, though, above all things, I could wish it; and do take it as a mighty respect to have been named there."

At last, at the end of twenty years from the time of his entry into the Royal Society, his associates showed the estimation in which they held him by electing him President on December $\mathrm{I}, \mathrm{r684}$. He was the sixth who filled that office in the history of the society. The council minute-book shows that he obtained twenty-nine votes out of thirty-nine, and that he was sworn in upon December ro. The council included at that time Sir Christopher Wren, Dr. Martin Lister, Robert Hooke, E. Halley, John Flamsteed (Astronomer Royal), John Evelyn, and Sir John Hoskyns. The difficulty which Pepys would have had in attending the meetings of council appears to have still continued after his election to the presidency, for he was only occasionally able to be present. Unfortunately, the Diary, which gives such a full and 